CHRONIC OBSTRUCTIVE PULMONARY DISEASE

\title{
Raised CRP levels mark metabolic and functional impairment in advanced COPD
}

\author{
R Broekhuizen, E F M Wouters, E C Creutzberg, A M W J Schols
}

Thorax 2006;61:17-22. doi: 10.1136/thx.2005.041996

See end of article for authors' affiliations

Correspondence to:

Dr R Broekhuizen,

Department of Respiratory

Medicine, University

Hospital Maastricht, P O

Box 5800, 6202 AZ

Maastricht, The

Netherlands;

r.broekhuizen@pul.

unimaas.nl

Received 6 February 2005

Accepted 24 July 2005

Published Online First

29 July 2005
Background: C-reactive protein (CRP) is often used as a clinical marker of acute systemic inflammation. Since low grade inflammation is evident in chronic diseases such as chronic obstructive pulmonary disease (COPD), new methods have been developed to enhance the sensitivity of CRP assays in the lower range. A study was undertaken to investigate the discriminative value of high sensitivity CRP in COPD with respect to markers of local and systemic impairment, disability, and handicap.

Methods: Plasma CRP levels, interleukin 6 (IL-6) levels, body composition, resting energy expenditure (REE), exercise capacity, health status, and lung function were determined in 102 patients with clinically stable COPD (GOLD stage II-IV). The cut off point for normal versus raised CRP levels was $4.21 \mathrm{mg} /$ I. Results: CRP levels were raised in 48 of 102 patients. In these patients, IL-6 ( $p<0.001$ ) and REE (adjusted for fat-free mass, $p=0.002)$ were higher while maximal $(p=0.040)$ and submaximal exercise capacity $(p=0.017)$ and 6 minute walking distance $(p=0.014)$ were lower. The SGRQ symptom score $(p=0.003)$ was lower in patients with raised CRP levels, as were post-bronchodilator $\operatorname{FEV}_{1}(p=0.031)$ and reversibility $(p=0.001)$. Regression analysis also showed that, when adjusted for $F E V_{1}$, age and sex, CRP was a significant predictor for body mass index $(p=0.044)$ and fat mass index $(p=0.016)$.

Conclusions: High sensitivity CRP is a marker for impaired energy metabolism, functional capacity, and distress due to respiratory symptoms in COPD.
$\mathrm{T}$ here is increasing evidence that chronic obstructive pulmonary disease (COPD) is a multiorgan systemic disease. Skeletal muscle weakness and wasting and impaired exercise performance have been well described as frequently occurring symptoms in advanced COPD. These features are poorly related to the severity of airflow limitation but appear to be linked to a systemic inflammatory response. ${ }^{1}$ As reviewed by Gan et al, ${ }^{2}$ several systemic inflammatory mediators such as tumour necrosis factor $\alpha$ (TNF- $\alpha)$, some interleukins (ILs), acute phase proteins (C-reactive protein (CRP), fibrinogen, lipopolysaccharide binding protein (LBP)) and leucocytes are increased in COPD. ${ }^{2}$ One of the markers of systemic inflammation that is consistently shown to be slightly increased in patients with COPD compared with healthy controls is CRP. ${ }^{2}$ The prevalence of increased CRP in COPD has been examined in the Third National Health and Nutrition Examination Survey (NHANES III); $31 \%$ of patients with moderate COPD (forced expiratory volume in l second $\left(\mathrm{FEV}_{1}\right) \geqslant 50-80 \%$ predicted) had a CRP level of $>3 \mathrm{mg} / \mathrm{l}$ and $6 \%$ had a level of $>10 \mathrm{mg} / \mathrm{l}$, while $52 \%$ of patients with severe COPD ( $\mathrm{FEV}_{1}<50 \%$ predicted) had a CRP level of $>3 \mathrm{mg} / \mathrm{l}$ and $23 \%$ had a level of $>10 \mathrm{mg} / \mathrm{l}$.

Patients with COPD with slightly raised CRP levels have not yet been characterized, and no studies have been undertaken to explore the potential role for CRP as a marker of local or systemic impairment. The aim of the present study was to investigate whether an increased concentration of high sensitivity CRP is related to the degree of lung function impairment, systemic inflammation, body composition, exercise capacity, energy metabolism, and quality of life in patients with advanced COPD.

\section{METHODS}

Subjects

Patients with clinically stable COPD consecutively admitted to an inpatient pulmonary rehabilitation centre (Asthma Centre Hornerheide, Horn, The Netherlands) were included in the study if they met the American Thoracic Society (ATS) criteria for COPD. ${ }^{4}$ Patients were excluded if they had concurrent diseases such as malignancies, gastrointestinal or kidney abnormalities, metabolic or endocrine diseases, and inflammatory diseases since raised CRP levels have also been described in these conditions. Twenty age matched healthy volunteers were recruited from an advertisement in a local newspaper for baseline cytokine measurement. Before inclusion in the study the healthy controls were fully examined by a chest physician for lung impairment, cardiovascular disease, diabetes, or other diseases.

\section{Pulmonary function}

Forced expiratory volume in 1 second $\left(\mathrm{FEV}_{1}\right)$, forced vital capacity (FVC), and inspiratory vital capacity (IVC) were calculated from the flow-volume curve using a spirometer (Masterlab, Jaeger, Würzburg, Germany). The highest value of at least three measurements was used. $\mathrm{FEV}_{1}$ was also calculated 15 minutes after inhalation of a $\beta$ agonist via a metered dose inhaler. Carbon monoxide transfer factor (TLCO) was determined using the single breath method (Masterlab). Lung function parameters were expressed as a percentage of reference values. ${ }^{5}$

For arterial blood gas analysis, blood was drawn from the brachial artery while the patients were breathing room air or using their oxygen when indicated $(n=16)$. Arterial oxygen and carbon dioxide tensions $\left(\mathrm{PaO}_{2}\right.$ and $\left.\mathrm{PaCO}_{2}\right)$ were analysed with a blood gas analyser (Radiometer, ABL 330, Copenhagen, Denmark).

\footnotetext{
Abbreviations: $\mathrm{BMI}$, body mass index; $\mathrm{COPD}$, chronic obstructive pulmonary disease; CRP, C-reactive protein; FFMI, fat-free mass index; FM, fat mass; $F E V_{1}$, forced expiratory volume in 1 second; FVC, forced vital capacity; $\mathrm{PaO}_{2}$, arterial oxygen tension; $\mathrm{PaCO}_{2}$, carbon dioxide tension; RER, respiratory exchange ratio; TLCO, carbon monoxide transfer factor; $\mathrm{V}$ E, ventilation; $\dot{\mathrm{V}}_{2}$, oxygen consumption; $\dot{\mathrm{V}} \mathrm{CO}_{2}$, carbon dioxide production
} 


\section{Body composition}

Body mass index (BMI) was calculated as weight divided by height $^{2}\left(\mathrm{~kg} / \mathrm{m}^{2}\right)$. Fat-free mass (FFM; $\mathrm{kg}$ ) was estimated using single frequency $(50 \mathrm{kHz})$ bioelectrical impedance analysis (BIA; Xitron Technologies, San Diego, CA, USA), with subjects in the supine position and calculated using the COPD specific equation. ${ }^{6}$ FFM index (FFMI) was calculated as FFM divided by height ${ }^{2}\left(\mathrm{~kg} / \mathrm{m}^{2}\right)$. Fat mass (FM; $\mathrm{kg}$ ) was estimated as total body weight minus FFM. Percentage FM was calculated by dividing FM by total body weight $\times 100 \%$.

\section{Energy expenditure}

Resting energy expenditure (REE) was measured in the early morning (08.30 hours) by indirect calorimetry using a ventilated hood (Oxycon Beta; Jaeger, Würzburg, Germany) after at least 10 hours of fasting. When patients were on additional oxygen during rehabilitation, the oxygen was temporarily withdrawn 30 minutes before and during measurement of REE. REE was calculated from oxygen consumption $\left(\dot{\mathrm{V}}_{2}\right)$ and carbon dioxide production $\left(\dot{\mathrm{V}}_{2}\right)$ using the abbreviated Weir formula. ${ }^{7}$ The ratio of REE to FFM was used for statistical analysis.

\section{Blood sampling}

Fasting EDTA blood was collected in the early morning (08.00-10.00 hours). Soluble tumour necrosis factor receptor 55 (sTNF-R55) and sTNF-R75 were measured in duplicate using the enzyme linked immunosorbent assay (ELISA) protocol as previously described by Leeuwenberg et al. ${ }^{8}$ Lower detection limits for the essays were $40 \mathrm{ng} / \mathrm{ml}$ for sTNF-R55 and $70 \mathrm{ng} / \mathrm{ml}$ for sTNF-R75. IL- 6 and TNF- $\alpha$ were determined in duplicate with a Quantikine high sensitivity ELISA (R\&D Systems, Minneapolis, USA) with lower detection limits of $0.039 \mathrm{pg} / \mathrm{ml}$ for IL- 6 and $0.5 \mathrm{pg} / \mathrm{ml}$ for total TNF- $\alpha$. C-reactive protein (CRP) was assessed in duplicate by high sensitivity particle enhanced immunonephelometry (Dade Behring) with a lower detection limit of $0.159 \mathrm{mg} / \mathrm{l}$.

\section{Exercise performance}

\section{Incremental bicycle ergometry test}

An incremental bicycle ergometry test was performed on an electromagnetic braked ergometer (Corival 400, Lode, Groningen, The Netherlands). After a 2 minute resting period and 1 minute unloaded cycling, power was increased every minute by 10 Watts. None of the subjects knew the exercise load and all were encouraged to cycle at $60 \mathrm{revs} / \mathrm{min}$ until exhaustion. In the 63 patients who did not desaturate $\left(\mathrm{PaO}_{2}\right.$ $<88 \%$ ) during the exercise tests, $\dot{\mathrm{V}} \mathrm{O}_{2}$ and $\dot{\mathrm{V}}_{\mathrm{CO}_{2}}$ were measured and calculated from breath by breath analysis using a breathing mask (Oxycon Beta, Jaeger, Würzburg, Germany).

\section{Submaximal bicycle ergometry test}

Patients performed a submaximal bicycle test of 2 minutes unloaded cycling, 10 minutes at $50 \%$, followed by maximally 20 minutes at $70 \%$ of individually measured peak workload of the incremental bicycle ergometry test to assess total endurance time and net mechanical efficiency. Mechanical efficiency was calculated using the following equation:

Net mechanical efficiency ${ }^{9}=(\operatorname{load}(\mathrm{W})$ of exercise $\times$ $0.01433(\mathrm{kcal} / \mathrm{min})) /($ energy expenditure during exercise (at $50 \%$ of peak workload) - REE $(\mathrm{kcal} / \mathrm{min})) \times 100 \%$

Energy expenditure during exercise mentioned in the equation was calculated using the steady state values of $\dot{\mathrm{V}}_{2}$ and $\dot{\mathrm{V}}_{\mathrm{CO}_{2}}$ and the abbreviated Weir formula. ${ }^{7}$ Good reproducibility of this method in patients with COPD has been described previously. ${ }^{10}$

\section{6 minute walking distance}

Exercise performance was also measured using a 6 minute walk test according to a standardised protocol. ${ }^{11}$

\section{Health related quality of life}

Health related quality of life was measured by the St George's Respiratory Questionnaire (SGRQ). The SGRQ consists of three subcategories-symptoms (distress due to respiratory symptoms), activity (disturbance of physical activity), and impact (overall impact on daily life and well being) - that combine into the total score (mean of the three subcategories). Subscores ranged from 0 to 100 with a higher score meaning greater impairment. A difference of 4 points in the total score is considered clinically significant. ${ }^{12}$

\section{Statistical analysis}

The median (range) CRP level of healthy age matched controls was $1.82(0.16-7.09) \mathrm{mg} / \mathrm{l}$. The cut off point of normal versus raised CRP levels was determined at $4.21 \mathrm{mg} / \mathrm{l}$, which was the 95th percentile of the CRP values of these healthy controls.

The results are presented as mean (SD) for all variables that were normally distributed and as median (range) when not normally distributed. Differences between the groups (normal $v$ raised CRP) were analysed using the Student's $t$ test for independent samples and using the Mann-Whitney $U$ test when not normally distributed. Regression analysis adjusting for FFM (when appropriate), lung function (postbronchodilator $\mathrm{FEV}_{1}$ (\% predicted) and TLCO (\% predicted)), age, and sex was used to establish the variables that were influenced by log transformed CRP presented as regression coefficient $(\beta)$ with $95 \%$ confidence intervals. Stepwise regression was used to select the variables that influenced log transformed CRP. Correlations between parameters were calculated with either Pearson or Spearman's correlation test. Data were analysed using Statistical Package for the Social Sciences (SPSS) Version 11.0 for Windows (SPSS Inc, Chicago, IL, USA). A p value of $<0.05$ was considered significant.

\section{RESULTS}

On hundred and two patients with COPD (71 men) of mean (SD) age 63 (9) years were included in the study, of whom 22 had GOLD stage II, 37 GOLD stage III, and 43 GOLD stage IV COPD. Patients were using the following pulmonary maintenance medication: $89 \% \quad \beta_{2}$ sympathicomimetics, $37 \%$ theophylline, $76 \%$ ipratropium bromide, $30 \%$ oral corticosteroids, $58 \%$ inhaled corticosteroids, and $58 \%$ oral $\mathrm{N}$-acetylcysteine.

The median (range) CRP level was 3.47 (0.36-75.60) mg/l. Twenty six patients $(25 \%)$ had a CRP level higher than $10 \mathrm{mg} / \mathrm{l}(21.25$ (11.5-75.6) mg/l). Patients with GOLD stages III and IV had significantly higher CRP levels than those with GOLD stage II (II: 1.92 (0.36-16.00) mg/l; III: 4.43 (0.4775.60) mg/l; IV: $4.90(0.47-65.70) \mathrm{mg} / \mathrm{l}$; both $\mathrm{p}<0.03)$.

The CRP level was raised (higher than $4.21 \mathrm{mg} / \mathrm{l}$ ) in $47 \%$ of the 102 patients ( 37 men and 11 women), who had a median CRP level of $12.50(4.29-75.60) \mathrm{mg} / \mathrm{l}$. Patients with normal CRP levels ( 34 men and 20 women) had a median level of 1.49 (0.36-4.07) mg/l. BMI, body composition, and lung function of patients with normal and raised CRP levels are shown in table 1. Age, sex, smoking history, and body composition were not significantly different between the two groups. Post-bronchodilator $\mathrm{FEV}_{1}$ was more impaired in patients with raised CRP levels $(p=0.031)$. In addition, patients with raised CRP levels had less reversible $\mathrm{FEV}_{1}$ than patients with normal CRP levels $(\mathrm{p}=0.001)$.

CRP was moderately inversely correlated with postbronchodilator $\mathrm{FEV}_{1}(r=-0.22, \mathrm{p}=0.026)$ and reversibility 


\begin{tabular}{|c|c|c|c|}
\hline & $\begin{array}{l}\text { Normal CRP } \\
(n=54)\end{array}$ & $\begin{array}{l}\text { Raised CRP } \\
(\mathrm{n}=48)\end{array}$ & p value \\
\hline$M / F$ & $34 / 20$ & $37 / 11$ & 0.122 \\
\hline Age (years) & $61.3(10.2)$ & $64.7(8.0)$ & 0.062 \\
\hline Smoking history* & $30.0(0-80)$ & $35.0(0-125)$ & 0.777 \\
\hline \multicolumn{4}{|l|}{ Body composition } \\
\hline BMI $\left(\mathrm{kg} / \mathrm{m}^{2}\right)$ & $21.9(4.1)$ & $22.8(3.3)$ & 0.209 \\
\hline FFMI $\left(\mathrm{kg} / \mathrm{m}^{2}\right)$ & $15.8(2.1)$ & $16.1(1.7)$ & 0.363 \\
\hline FM (\%) & $27.0(7.8)$ & $28.9(6.3)$ & 0.191 \\
\hline \multicolumn{4}{|l|}{ Lung function } \\
\hline FEV 1 (pre) (\% predicted) & $35.9(14.3)$ & $33.1(12.4)$ & 0.294 \\
\hline $\mathrm{FEV}_{1}$ (post) (\% predicted) & $39.9(15.3)$ & $33.8(12.2)$ & 0.031 \\
\hline FVC (\% predicted) & $78.0(17.9)$ & $75.3(18.7)$ & 0.472 \\
\hline Reversibility (\% predicted) & $2.9(-8.3-13.0)$ & $0.0(-7.2-8.7)$ & 0.001 \\
\hline $\mathrm{FEV}_{1} / \mathrm{FVC}(\%)$ & $36(9)$ & $35(9)$ & 0.366 \\
\hline TLCO (\% predicted) & $50.7(19.7)$ & $47.4(20.2)$ & 0.423 \\
\hline $\mathrm{PaO}_{2}(\mathrm{kPa})$ & $9.34(1.26)$ & $9.17(1.15)$ & 0.460 \\
\hline $\mathrm{PaCO}_{2}(\mathrm{kPa})$ & $5.49(0.87)$ & $5.48(0.87)$ & 0.538 \\
\hline \multicolumn{4}{|c|}{$\begin{array}{l}\text { Values are mean (SD) unless stated otherwise. } \\
\mathrm{BMI} \text {, body mass index; FFMI, fat-free mass index; } \mathrm{FM} \text {, fat mass; } \mathrm{FEV}_{1} \text {, forced expiratory volume in } 1 \text { second; pre } \\
\text { pre-bronchodilator; post, post-bronchodilator; } \mathrm{FVC} \text {, forced vital capacity; TLCO, carbon monoxide transfer factor } \\
\mathrm{PaO}_{2} \text {, arterial oxygen tension; } \mathrm{PaCO}_{2} \text {, carbon dioxide tension. } \\
{ }^{*} \mathrm{Median}^{-} \text {(range) non-parametrically tested with Mann-Whitney U test. }\end{array}$} \\
\hline
\end{tabular}

$(r=-0.35, \mathrm{p}<0.001)$. No differences were found between patients with raised and normal CRP levels in maintenance medication or long term oxygen therapy $(n=16)$.

Inflammatory markers are shown in table 2. IL-6 was increased in patients with raised CRP levels $(p<0.001)$ and correlated with CRP $(r=0.59, \mathrm{p}<0.001)$. In addition, sTNFR55 was higher in patients with raised CRP levels $(p=0.024)$ and also correlated mildly with CRP $(r=0.25, \mathrm{p}=0.012)$, whereas TNF- $\alpha$ and TNF-R75 were not significantly different between the CRP groups. COPD patients in both groups had higher IL-6 levels than healthy controls (both $\mathrm{p}<0.005$ ). Soluble TNF-R75 was significantly increased in patients with raised CRP levels $(p=0.003)$ and tended to be higher in patients with normal CRP levels $(p=0.056)$ than in healthy controls.

Exercise capacity was assessed with three tests (table 3). In all three tests, exercise capacity was more impaired in the COPD patients with raised CRP levels than in those with normal CRP levels $(\mathrm{p} \leqslant 0.04)$. Log transformed CRP was moderately inversely correlated with load/FFM $(r=-0.25$, $\mathrm{p}=0.012)$, walking distance $(r=-0.27, \mathrm{p}=0.007)$, and duration time $(r=-0.29, \mathrm{p}=0.010)$.

REE adjusted for FFM was higher in patients with raised CRP levels $(31.4(5.4) \mathrm{kcal} / \mathrm{kg})$ than in those with normal CRP levels (28.0 (4.8) kcal $/ \mathrm{kg}, \mathrm{p}=0.002$; fig 1). CRP was positively correlated with REE/FFM $(r=0.31, \mathrm{p}=0.002)$ and with REE $(r=0.41, \mathrm{p}<0.001)$.

Figure 2 shows the health status scores for both groups. Patients with raised CRP levels tended to have a higher total score on the SGRQ (51.5 (13.9) points) than those with normal CRP levels (47.0 (10.9) points; $\mathrm{p}=0.095$; difference 4.5 points). A difference of 4 points is considered clinically significant. ${ }^{12}$ Patients with raised CRP levels had a significantly higher score on the symptom domain than those with normal CRP levels (64.7 (16.5) points $v 54.2$ (17.1) points; $\mathrm{p}=0.003)$.

Regression analysis adjusted for post-bronchodilation $\mathrm{FEV}_{1}$, TLCO, age, FFM, and sex showed that log transformed CRP seemed to be a significant and independent predictor for time cycled submaximal ergometry $(\beta=-3.105$ (95\% CI -5.986 to -0.224$), p=0.035)$. Log transformed CRP also seemed to be a significant predictor for REE ( $\beta=164$ (95\% CI 91 to 236$), p<0.001)$, IL-6 ( $\beta=3.409$ (95\% CI: $2.308,4.504)$, $\mathrm{p}<0.001)$, post-bronchodilation $\mathrm{FEV}_{1}(\beta=-5.48$ (95\% CI -10.30 to -0.66$), p<0.026)$ and reversibility $(\beta=-2.52$ (95\% CI -4.38 to -0.66$), \mathrm{p}=0.008)$, and for the symptom score of the SGRQ ( $\beta=8.282$ (95\% CI 1.345 to 15.220$)$, $\mathrm{p}=0.020$ ). Interestingly, log transformed CRP also seemed to be a significant predictor of BMI ( $\beta=1.376$ (95\% CI 0.039 to $2.713), p=0.044)$, which was a reflection of the relation of CRP with FMI ( $\beta=1.103$ (95\% CI 0.213 to 1.994$), p=0.016)$ but not of FFMI $(\beta=0.273$ (95\% CI -0.367 to 0.913 ), $\mathrm{p}=0.400$ ). The observation that body composition did not differ between the groups (table 1) can be explained by the different distribution in men and women.

Stepwise regression showed that IL-6 ( $\beta=0.075$ (95\% CI 0.041 to 0.109$), p<0.001$ ), $\operatorname{REE}(\beta=0.0006$ ( $95 \%$ CI 0.000 to $0.001), \quad p=0.035)$, and 6 minute walking distance

\begin{tabular}{|c|c|c|c|}
\hline & \multicolumn{2}{|l|}{ COPD } & \multirow[b]{2}{*}{ Controls } \\
\hline & Normal CRP & Raised CRP & \\
\hline $\begin{array}{l}\text { TNF } \alpha \text { (pg/ml) } \\
\text { sTNF-R55 (ng/ml) } \\
\text { sTNF-R75 (ng/ml) } \\
\text { IL-6 (pg/ml) }\end{array}$ & $\begin{array}{l}1.25(0.60-3.42) \\
0.87(0.54-2.51) \\
1.42(0.81-3.39) \\
2.60(1.00-11.45)^{*}\end{array}$ & $\begin{array}{l}1.31(0.43-3.19) \\
1.00(0.59-2.20) \dagger \\
1.54(0.84-3.33)^{*} \\
6.45(0.90-12.85)^{\star} \dagger\end{array}$ & $\begin{array}{l}1.23(0.74-2.70) \\
0.88(0.59-1.46) \\
1.14(0.68-1.82) \\
1.76(0.81-6.00)\end{array}$ \\
\hline
\end{tabular}

Values presented as median (range)

TNF- $\alpha$, tumour necrosis factor $\alpha$; sTNF-R55/75, soluble TNF-receptor 55/75; IL-6, interleukin 6 . ${ }^{*} p<0.05 v$ healthy controls.

$\mathrm{tp}<0.03$ v normal CRP levels. 
Table 3 Exercise parameters in COPD patients with normal and raised CRP levels

\begin{tabular}{|c|c|c|c|}
\hline & Normal CRP & Raised CRP & $p$ value \\
\hline \multicolumn{4}{|l|}{ Incremental ergometry } \\
\hline Workload (W) & $63.0(29.3)$ & $51.8(24.0)$ & 0.040 \\
\hline Load/FFM (W/kg) & $1.38(0.59)$ & $1.11(0.49)$ & 0.015 \\
\hline$\dot{\mathrm{VO}}_{2}(\mathrm{ml} / \mathrm{min})$ & $996(333)$ & $894(268)$ & 0.116 \\
\hline$\dot{\mathrm{V}} \mathrm{CO}_{2}(\mathrm{ml} / \mathrm{min})$ & 989 (395) & $865(288)$ & 0.095 \\
\hline RER & $0.98(0.11)$ & $0.96(0.09)$ & 0.472 \\
\hline$\dot{V}_{E}(\mathrm{l} / \mathrm{min})$ & $38.6(13.0)$ & $37.3(10.3)$ & 0.629 \\
\hline$\dot{\mathrm{V}} \mathrm{E} / \mathrm{V}_{\mathrm{O}}$ & $39.4(7.1)$ & $42.9(8.6)$ & 0.046 \\
\hline$\dot{\mathrm{VO}}_{2} / \mathrm{load}^{*}(\mathrm{ml} / \mathrm{W})$ & $14.9(8.2-43.2)$ & $16.2(10.1-27.9)$ & 0.056 \\
\hline$\dot{\mathrm{V}} \mathrm{CO}_{2} /$ load$^{*}(\mathrm{ml} / \mathrm{W})$ & $14.7(7.2-35.7)$ & $15.9(10.6-27.9)$ & 0.133 \\
\hline \multicolumn{4}{|l|}{ Submaximal ergometry } \\
\hline Duration time $^{*}(\mathrm{~min})$ & $13(3-30)$ & $8(2-30)$ & 0.017 \\
\hline Efficiency* $(\%)$ & $16.2(5.5-25.5)$ & $14.2(8.1-19.4)$ & 0.138 \\
\hline \multicolumn{4}{|l|}{ 6-min walking distance } \\
\hline Distance (m) & $355(120)$ & $301(96)$ & 0.014 \\
\hline \multicolumn{4}{|c|}{$\begin{array}{l}\text { Values are mean (SD) unless otherwise indicated. All incremental ergometry test parameters are shown as peak } \\
\text { values. } \\
\mathrm{FFM} \text {, fat-free mass; } \dot{\mathrm{V}}_{2} \text {, oxygen consumption; } \dot{\mathrm{V}}_{\mathrm{CO}} \text {, carbon dioxide production; RER, respiratory exchange ratio; } \\
\dot{\mathrm{V}} \mathrm{E} \text {, ventilation. } \\
{ }^{*} \text { Median (range) non-parametrically tested with the Mann-Whitney } \mathrm{U} \text { test. }\end{array}$} \\
\hline
\end{tabular}

$(\beta=-0.0012(95 \%$ CI -0.002 to 0.000$), p=0.020)$ were selected as predictors of log transformed CRP.

\section{DISCUSSION}

The aim of this study was to characterise COPD patients with raised CRP levels with respect to lung function, systemic inflammation, body composition, exercise capacity, energy metabolism, and quality of life. The main findings were that, irrespective of $\mathrm{FEV}_{1}$, COPD patients with a raised plasma level of CRP had more impaired energy metabolism, increased disability as defined by impaired exercise capacity, and more distress due to respiratory symptoms than patients with normal CRP levels. In addition, patients with raised CRP levels had lower post-bronchodilator $\mathrm{FEV}_{1}$ related to less reversibility in $\mathrm{FEV}_{1}$ after inhalation of a $\beta$ agonist than patients with normal CRP levels.

Reports on the relation between CRP levels and lung function have not been consistent. Results from NHANES III excluding patients with COPD showed an inverse relation between systemic CRP and $\mathrm{FEV}_{1} \cdot{ }^{13}$ This was also found in the Caerphilly Prospective Heart Disease Study which included only male patients with ischaemic heart disease. ${ }^{14}$ Although a smaller study did not find a correlation between CRP levels and lung function in patients with mild to severe COPD, ${ }^{15}$ CRP seems to increase with increasing severity of COPD. ${ }^{316}$ In

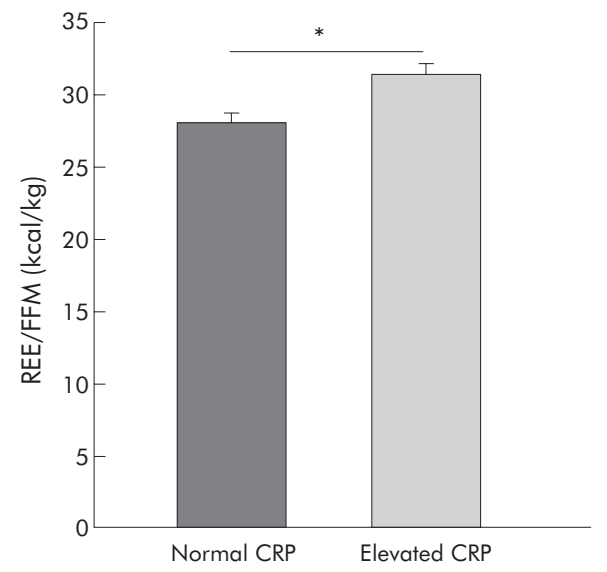

Figure 1 Mean (SE) resting energy expenditure (REE) adjusted for fatfree mass (FFM) in patients with normal and elevated CRP levels; ${ }^{*} \mathrm{p}<0.002$. this study we also found that post-bronchodilator $\mathrm{FEV}_{1}$ and reversibility were more impaired in patients with raised levels of CRP.

Although the exact origin of systemic inflammation is unknown, lung biopsy examination clearly shows that local inflammation is more pronounced with worse lung function. ${ }^{17}$ The higher level of systemic inflammation in COPD patients with low reversibility suggests a more inflammation driven airflow limitation, although no direct data of local inflammation were obtained in our study. However, at least two other studies of patients in the stable state have not found a direct relationship between the pulmonary and systemic compartments, suggesting that pulmonary and systemic inflammation may be modulated separately. ${ }^{18}$ Interestingly, TLCo did not differ between the two groups, which suggests that exercise induced intermittent hypoxaemia did not differ between them. Differences in the presence of potentially pathogenic micro-organisms (PPM) in the sputum might be another difference between the two patient groups as it has previously been shown that the presence of sputum PPM in patients with stable COPD is associated with greater systemic inflammation. ${ }^{19}$ Future

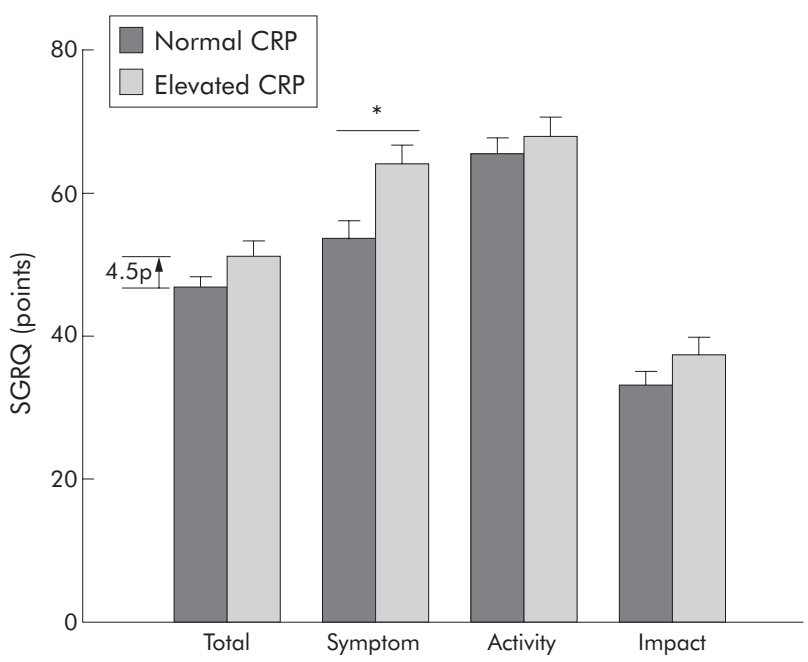

Figure 2 Quality of life as measured with the St George's Respiratory Questionnaire in patients with normal and elevated CRP levels. The total score was 4.5 points higher in patients with elevated CRP. Data are presented as mean (SE). ${ }^{*} p=0.003$. 
studies are needed to explore the relationship between the systemic inflammatory response and the level of pulmonary inflammation.

The association between CRP and IL-6 levels is well established. Previously, IL-6 was identified as an "exercise factor", being produced by contracting muscle and subsequently released into the blood. Under normal circumstances the IL- 6 gene is rapidly activated during exercise. It has been shown that IL-6 gene transcription is mediated by the glycogen content ${ }^{20}$ and that increased IL-6 expression is associated with increased glucose uptake during exercise. ${ }^{21}$ IL-6 is therefore thought to act as an energy sensor in response to exercise. When contracting muscles are low in glycogen, IL-6 is released to increase glucose uptake and induce lipolysis and gene transcription in abdominal subcutaneous fat. ${ }^{21}$ However, it has also been shown that murine myotubes express IL- 6 when exposed to oxidative stress, ${ }^{22}$ and that oral supplementation with antioxidants can attenuate exercise induced plasma IL-6 in healthy humans. ${ }^{23}$ Fischer $e \mathrm{al}^{23}$ have shown that supplementation of vitamin C in combination with vitamin $\mathrm{E}$ resulted in lower exercise induced plasma IL-6 levels, while no differences were found in muscle IL-6 mRNA or in skeletal muscle IL-6 protein expression. This suggests that the release of IL- 6 from the muscle was inhibited by the antioxidants. ${ }^{23}$

In COPD several changes have been reported that can influence the abovementioned process. Firstly, decreases in oxidative enzymes involved in carbohydrate and fatty acid oxidation have been reported in some patients with COPD. ${ }^{24}$ Furthermore, it has been shown that some COPD patients have impaired muscle glycogen content due to inactivity ${ }^{25}$ and hypoxia, ${ }^{26}$ and have enhanced lactic acid production during cycling compared with healthy control subjects. ${ }^{27}$ Systemically, patients with COPD also have an imbalance between oxidants and antioxidants at rest and also after exercise, suggestive of increased oxidative stress. ${ }^{28}$ Moreover, Rabinovich et $\mathrm{l}^{29}$ have shown that, unlike healthy subjects, patients with COPD cannot adapt their muscle redox status to training.

We hypothesise that these changes could disturb the normal exercise induced rise in IL- 6 in COPD via an earlier and exacerbated induction of IL- 6 at a lower exercise load. IL6 would thus be a marker for impairment of exercise metabolism. Imbalances between oxidants and antioxidants could increase the release of IL-6 independently of muscle intrinsic changes. Because IL- 6 is a strong inducer of acute phase proteins, ${ }^{30}$ the exacerbated increase in IL-6 production of muscle could induce CRP, as illustrated by the strong correlation between CRP and IL-6 in this study. Such an increase in CRP after exercise has been shown to occur in healthy subjects. ${ }^{23}$ Other studies have also shown an inverse relation between CRP and exercise capacity in healthy elderly subjects $^{31}$ as well as in those with COPD. ${ }^{28}$

The increased demand for specific amino acid to generate CRP may increase muscle protein breakdown, increasing REE $^{32}$ and inducing a vicious cycle of intrinsic muscle changes leading to decreased exercise capacity leading to more muscle impairment. CRP may thus be a marker of a repetitive supraphysiological increase in IL-6 production of muscle in a subgroup of COPD patients. Previous research has also shown an association between systemic inflammation as measured by markers of the TNF system and weight loss. ${ }^{33}$ In this study we showed an association between CRP and BMI (when adjusted for post-bronchodilation $\mathrm{FEV}_{1}$, TLCo, age, and sex) that could be attributed to FMI, but not to FFMI. The association between CRP and extent of obesity has previously been found in studies with non-diabetic subjects. ${ }^{34}$ It has been proposed that inflammatory cytokines could be secreted by adipocytes and by inflammatory cells present in adipose tissue. ${ }^{35}$ Further research is needed to elucidate the effect of different cytokines on body composition and vice versa.

The cut off point used in this study is not the standard cut off point of $5 \mathrm{mg} / \mathrm{l}$ which is often used in clinical practice. Interestingly, our cut off point, determined as the 95th percentile of our own healthy age and sex matched controls, is very similar to the clinical cut off point. In addition, analysis using 3 or $5 \mathrm{mg} / \mathrm{l}$ as the cut off point provided the same results (data not shown).

High sensitivity CRP analysis has already been recommended for clinical application in the detection and prevention of cardiovascular disease. ${ }^{36}$ Since cardiovascular disease is a major cause of mortality in COPD, ${ }^{37}$ and CRP is a predictor of acute exacerbations of COPD, ${ }^{38}$ hospital admissions, and mortality in chronic respiratory failure ${ }^{39}$ and seems to be a marker for impaired exercise capacity and distress due to respiratory symptoms (as shown in this study), routine high sensitivity CRP analysis could prove to be of major clinical importance in COPD. Future research is needed to assess the value of CRP as a biomarker for measuring disease progress and the effects of treatment of COPD.

\section{Authors' affiliations}

R Broekhuizen, E F M Wouters, A M W J Schols, Department of Respiratory Medicine, University Hospital Maastricht, The Netherlands E C Creutzberg, Asthma Centre Hornerheide, Horn, The Netherlands

Supported by GlaxoSmithKline.

Competing interests: EFMW serves as a consultant to GlaxoSmithKline (GSK) and is a member of the scientific advisory board for GSK. He received lecture fees and research grants between 2001 and 2004 from GSK. None of the other authors has any conflict of interest to disclose.

Written informed consent was obtained from all subjects and the ethical review board of the University Hospital Maastricht approved the study.

\section{REFERENCES}

1 ATS/ERS. Skeletal muscle dysfunction in chronic obstructive pulmonary disease. A statement of the American Thoracic Society and European Respiratory Society. Am J Respir Crit Care Med 1999;159:S1-40.

2 Gan WQ, Man SF, Senthilselvan A, et al. Association between chronic obstructive pulmonary disease and systemic inflammation: a systematic review and a meta-analysis. Thorax 2004;59:574-80

3 Mannino DM, Ford ES, Redd SC. Obstructive and restrictive lung disease and markers of inflammation: data from the Third National Health and Nutrition Examination. Am J Med 2003;1 14:758-62.

4 American Thoracic Society. Standards for the diagnosis and care of patients with chronic obstructive pulmonary disease. Am J Respir Crit Care Med 1995; 152:S77-121.

5 Quanjer PH. Standardized lung function testing. Official statement of the European Respiratory Society. Eur Respir J 1993;6(Suppl 16):1-100.

6 Steiner MC, Barton RL, Singh SJ, et al. Bedside methods versus dual energy Xray absorptiometry for body composition measurement in COPD. Eur Respir J 2002; 19:626-31.

7 Weir JB. New methods for calculating metabolic rate with special reference to protein metabolism. Nutrition 1990;6:213-21.

8 Leeuwenberg JF, Jeunhomme TM, Buurman WA. Slow release of soluble TNF receptors by monocytes in vitro. J Immunol 1994;152:4036-43.

9 Gaesser GA, Brooks GA. Muscular efficiency during steady-rate exercise: effects of speed and work rate. J Appl Physiol 1975;38:1132-9.

10 Baarends EM, Schols AM, Akkermans MA, et al. Decreased mechanical efficiency in clinically stable patients with COPD. Thorax 1997:52:981-6.

11 American Thoracic Society. ATS statement: guidelines for the six-minute walk test. Am J Respir Crit Care Med 2002;166:111-7.

12 Jones PW. Issues concerning health-related quality of life in COPD. Chest 1995;107(5 Suppl):187-93S.

13 Cirillo DJ, Agrawal Y, Cassano PA. Lipids and pulmonary function in the Third National Health and Nutrition Examination Survey. Am J Epidemiol 2002; 155:842-8

14 Mendall MA, Strachan DP, Butland BK, et al. C-reactive protein: relation to total mortality, cardiovascular mortality and cardiovascular risk factors in men. Eur Heart J 2000;21:1584-90.

15 Dentener MA, Creutzberg EC, Schols AM, et al. Systemic anti-inflammatory mediators in COPD: increase in soluble interleukin 1 receptor II during treatment of exacerbations. Thorax 2001;56:721-6.

16 Sin DD, Man SF. Why are patients with chronic obstructive pulmonary disease at increased risk of cardiovascular diseases? The potential role of systemic 
inflammation in chronic obstructive pulmonary disease. Circulation 2003; 107:1514-9.

17 Hogg JC, Chu F, Utokaparch S, et al. The nature of small-airway obstruction in chronic obstructive pulmonary disease. N Engl J Med 2004;350:2645-53.

18 Vernooy JH, Kucukaycan M, Jacobs JA, et al. Local and systemic inflammation in patients with chronic obstructive pulmonary disease: soluble tumor necrosis factor receptors are increased in sputum. Am J Respir Crit Care Med 2002; 166:1218-24.

19 Baneriee D, Khair OA, Honeybourne D. Impact of sputum bacteria on airway inflammation and health status in clinical stable COPD. Eur Respir J 2004;23:685-91.

20 Keller C, Steensberg A, Pilegaard H, et al. Transcriptional activation of the IL-6 gene in human contracting skeletal muscle: influence of muscle glycogen content. FASEB J 2001;15:2748-50.

21 Pedersen BK, Steensberg A, Fischer C, et al. The metabolic role of IL-6 produced during exercise: is IL-6 an exercise factor? Proc Nutr Soc 2004;63:263-7.

22 Kosmidou I, Vassilakopoulos T, Xagorari A, et al. Production of interleukin-6 by skeletal myotubes: role of reactive oxygen species. Am J Respir Cell Mol Biol 2002;26:587-93.

23 Fischer CP, Hiscock NJ, Penkowa $M$, et al. Supplementation with vitamins $C$ and $E$ inhibits the release of interleukin-6 from contracting human skeletal muscle. J Physiol 2004;558:633-45.

24 Maltais $F$, LeBlanc $P$, Whittom $F$, et al. Oxidative enzyme activities of the vastus lateralis muscle and the functional status in patients with COPD. Thorax 2000;55:848-53

25 Engelen MP, Schols AM, Does JD, et al. Exercise-induced lactate increase in relation to muscle substrates in patients with chronic obstructive pulmonary disease. Am J Respir Crit Care Med 2000;162:1697-704.

26 Jakobsson $P$, Jorfeldt L, Brundin A. Skeletal muscle metabolites and fibre types in patients with advanced chronic obstructive pulmonary disease (COPD), with and without chronic respiratory failure. Eur Respir J 1990;3:192-6.

27 Maltais F, Simard AA, Simard C, et al. Oxidative capacity of the skeletal muscle and lactic acid kinetics during exercise in normal subjects and in patients with COPD. Am J Respir Crit Care Med 1996;153:288-93.
28 Koechlin C, Couillard A, Cristol JP, et al. Does systemic inflammation trigger local exercise-induced oxidative stress in COPD? Eur Respir $J$ 2004;23:538-44.

29 Rabinovich RA, Ardite E, Troosters T, et al. Reduced muscle redox capacity after endurance training in patients with chronic obstructive pulmonary disease. Am J Respir Crit Care Med 2001;164:1114-8.

30 Kishimoto T. The biology of interleukin-6. Blood 1989;74:1-10.

31 Geffken DF, Cushman M, Burke GL, et al. Association between physical activity and markers of inflammation in a healthy elderly population. Am J Epidemiol 2001;153:242-50.

32 Reeds PJ, Fjeld CR, Jahoor F. Do the differences between the amino acid compositions of acute-phase and muscle proteins have a bearing on nitrogen loss in traumatic states? J Nutr 1994;124:906-10.

33 Di Francia M, Barbier D, Mege JL, et al. Tumor necrosis factor-alpha levels and weight loss in chronic obstructive pulmonary disease. Am J Respir Crit Care Med 1994;150:1453-5.

34 Yudkin JS, Stehouwer CD, Emeis JJ, et al. C-reactive protein in healthy subjects: associations with obesity, insulin resistance, and endothelial dysfunction: a potential role for cytokines originating from adipose tissue? Arterioscler Thromb Vasc Biol 1999;19:972-8.

35 Weisberg SP, McCann D, Desai M, et al. Obesity is associated with macrophage accumulation in adipose tissue. J Clin Invest 2003; 1 12:1796-808.

36 Ridker PM. Clinical application of C-reactive protein for cardiovascular disease detection and prevention. Circulation 2003;107:363-9.

37 Hansell AL, Walk JA, Soriano JB. What do chronic obstructive pulmonary disease patients die from? A multiple cause coding analysis. Eur Respir J 2003;22:809-14.

38 Dev D, Wallace E, Sankaran R, et al. Value of C-reactive protein measurements in exacerbations of chronic obstructive pulmonary disease. Respir Med 1998;92:664-7.

39 Cano NJ, Pichard C, Roth $\mathrm{H}$, et al. C-reactive protein and body mass index predict outcome in end-stage respiratory failure. Chest 2004; 126:540-6.

\section{LUNG ALERT}

\section{Using serum osteopontin to help identify pleural mesothelioma}

$\Delta$ Pass HI, Lott D, Lonardo F et al. Asbestos exposure, pleural mesothelioma, and serum osteopontin levels. N Engl J Med 2005;353:1564-73

C erum osteopontin levels were compared in 76 patients with surgically staged pleural

S mesothelioma, 69 with non-malignant asbestos disease, and 45 non-exposed controls. Tumour osteopontin was also assessed in the patients with mesothelioma.

Comparing age matched subjects with and without exposure to asbestos (in the absence of malignant disease), the authors concluded that there were no significant differences in mean (SE) serum levels of osteopontin between the groups (30 (3) ng/ml and 20 (4) ng/ml, respectively; $p=0.06$ ). However, serum osteopontin levels were significantly higher in the group with pleural mesothelioma than in the asbestos exposed controls ( $133(10) \mathrm{ng} / \mathrm{ml} v 30$ (3) $\mathrm{ng} / \mathrm{ml}, \mathrm{p}<0.001)$. Thirty six of the 38 available samples of tumour tissue $(94.7 \%)$ stained positive for osteopontin on immunohistochemistry.

In the groups exposed to asbestos, Receiver-Operating-Characteristic (ROC) analysis of serum osteopontin levels noted a sensitivity of $77.6 \%$ and specificity of $85.5 \%$ (at a cut off of $48.3 \mathrm{ng} / \mathrm{ml}$ ) for the diagnosis of mesothelioma; this improved to $84.6 \%$ and $88.4 \%$, respectively, with a cut off value of $62.4 \mathrm{ng} / \mathrm{ml}$ for patients with confirmed stage I mesothelioma.

This study shows that tissue immunohistochemistry and serum ELISA assay for osteopontin can be used to help distinguish individuals with pleural mesothelioma from those with non-malignant pulmonary disease who have been exposed to asbestos.

C K Hui Senior Clinical Fellow, Royal Free Hospital, London, UK; Christopher.Hui@royalfree.nhs.uk 